УДК 373.2(438)

DOI:

Божена Мажец, докторант кафедри загальної педагогіки та дошкільної освіти Дрогобииького державного педагогічного університету імені Івана Франка

\title{
РЕФОРМУВАННЯ ДОШКІЛЬНОЇ ОСВІТИ ПОЛЬЩІ У ДОСЛІДЖЕННЯХ УКРАЇНСЬКИХ НАУКОВЦІВ
}

У статті проаналізовано дослідження українських науковців з проблеми модернізації дошкільноі освіти у Польщі. Звернуто увагу на ключові зміни у дошкільній освіті - у децентралізації влади, передачі дошкільних закладів у підпорядкування місиевої влади. Розкрито зміни у дошкільній освіті, зумовлені приєднанням Польщі до Європейського Союзу. Висвітлено иінність досліджень українських авторів щодо окремих змін у дошкільній освіті Польщі, які знайшли висвітлення як у публікаціях польських, так західноєвропейських дослідників.

Ключові слова: дошкільна освіта, навчальна програма, середовище, фінансування, Польща, дослідження украӥнських науковиів.

Лim. 18.

Bozhena Mazhets, Doctoral Student of the General Pedagogy and Preschool Council Department Drohobych Ivan Franko State Pedagogical University

\section{REFORM OF PRESCHOOL EDUCATION IN POLAND IN THE STUDIES OF UKRAINIAN SCHOLARS}

The aim of the article is to analyze the attitude of Ukrainian researchers to the changes that have occurred in pre-school education in Poland. Analyzing the foreign language literature, the author goes back to the work of such authors as: Ě. Babyazh, A. Vasylyuk, V. Pasichnyk, E. Savina, L. Lyashenko, L. Hrynevych, E. Korsak, O. Luhin, S. Derkach, W. Rohozina, S. Sisoyewa, T. Kristopchuk, S. V. Bocharov, J. R. Antonyuk, I. Bondarenko.

The author's interest aroused the point of view of the changes that took place in Polish pre-school education at the turn of the 20th and 21st centuries. On the basis of the analysis of selected texts, the author states that according to Ukrainian researchers, the decentralization of power and the transfer of kindergartens to the management of local authorities were of key importance for the changes in pre-school education. In the initial phase, it had both positive and negative effects. The positive factors include the better knowledge of the needs and expectations of the environment regarding pre-school education institutions. To others - financial problems of local administration authorities and the resulting liquidation of many kindergartens.

The Ukrainian authors also underline the impact of Poland becoming the European Union member and the related changes. They indicate, among other things: the possibility of establishing and running kindergartens by legal and natural persons, development of a unified program basis, the choice and development of preschool programs by teachers, the introduction of early support of child development, the introduction of foreign language learning in the pre-schools, the use of activating methods.

As a characteristic element of Polish pre-school education, they indicate conducting classes in groups of different ages. They also pay attention to the rules of recruitment to kindergartens and the fact that it is parents who decide at what age they send their child to kindergarten and for how many hours.

Due to the apperance of the problem of multiculturalism, the subject of integration and tolerance on the one hand, and, on the other, patriotic and regional education have taken on a whole new meaning.

Summing up the collected material, it is worth emphasizing that these days, when the whole world is becoming a global village, it is very important to raise new generations in respect of our own tradition, but also generations open to otherness. It is worth reaching out to the studies of our eastern neighbours, because they draw attention to such elements of changes that escape both Polish and Western European researchers.

Keywords: the pre-school education, core curriculum, an environment, financing, Poland, the Ukrainian researchers.

П остановка проблеми. Розвиток системи дошкільної совіти у Польщі, функціонування різних типів закладів дошкільної освіти різних форм власності, реалізація освітньої програми у цих інституціях, управління системою дошкільної совіти, професійне зростання педагогічних кадрів, зокрема вихователів, реформи, здійснені у Польщі у період суспільної трансформації, знайшли висвітлення на шпальтах педагогічної преси, стали предметом дослідження польських науковців. Ці проблеми викликають зацікавлення не тільки західноєвропейських дослідників, а й українських. 


\section{РЕФОРМУВАННЯ ДОШКІЛЬНОЇ ОСВІТИ ПОЛЬЩІ}

\section{У ДОСЛІДЖЕННЯХ УКРАЇНСЬКИХ НАУКОВЦІВ}

Висвітлюючи означену проблему, польські вчені посилаються переважно на праці вітчизняних та західноєвропейських дослідників. Вони деколи використовують доробок найближчих сусідів - українських науковців. Тим часом українські педагоги займаються питаннями освітніх реформ у Польщі. На увагу заслуговують публікації і дисертаційні дослідження М. Бабияж, А. Василюк, Л. Гриневич, К. Корсак, О. Лугіна, Л. Ляшенко, В. Пасічник, В. Рогозіна, К. Савина, С. Сисоєва та ін. Аналізуючи україномовну літературу, на нашу думку, в історіографії педагогічної думки Польщі ще недостатньо знайшло відображення переміни у галузі освіти, зокрема, дошкіллі.

Мета статті - окреслити проблеми змін дошкільної освіти у Польщі на зламі XX - XXI ст. у дослідженнях українських науковців.

Виклад основного матеріалу. Для сьогодення важливо врахувати власний досвід і досвід сусідів щодо проблем організації закладів дошкільної освіти. Українська дослідниця О. Лугіна звертає увагу на зміни у дошкільній освіті Польщі в післявоєнний період [10]. На основі статистичних даних та аналізу позитивних та негативних змін дошкільної освіти в Польщі автор розкриває тенденції розвитку дошкільних установ. Зазначає, що в післявоєнний період, одразу ж у червні 1945 p. на Національному конгресі з питань освіти в Лодзі запроваджено введення обов'язкової дошкільної освіти. У тому ж році Міністерство освіти видало інструкцію та рекомендувало створення дошкільної установи для дітей віком від 4 до 7 років. Ї̈̈ метою було створення умов для всебічного розвитку дитини, підготовка до життя в суспільстві та до навчання в школі.

О. Лугіна, використовуючи дослідження М. Кєлар [17], зазначає, що відповідно до положень Закону “Про систему освіти” дошкільна освіта охоплює дітей віком від 3 до 6 років, тобто перед початком початкової школи. Дошкільне виховання здійснюється у двох типах дошкільних навчальних закладів: дитячих садках та дошкільних осередків у початковій школі. У післявоєнний період кількість дитячих садів у Польщі продовжувала зростати майже до кінця 80-х років. У вісімдесятих їх було більше 26000. З 1990 р., коли дитячі садки перейшли в управління місцевого самоврядування, кількість філій з року в рік зменшується [16]. О. Лугіна привертає увагу до позитивних та негативних тенденцій, що виникли в 90-х роках у дошкільній освіті в Польщі. Серед негативних тенденцій виокремлено: скорочення кількості дошкільних закладів; ліквідація дитячих садків та дошкільних закладів у початкових школах (особливо в селах); скорочення кількості місць у дитячих садках (особливо в сільській місцевості); зниження рівня залучення дітей до дошкільної освіти до 42,7\% у 1993 році. До позитивних тенденцій віднесено: скорочення кількості дитячих садків, що, на її думку, може сприяти поліпшенню умов їх функціонування; зменшення кількості філій, що створює кращі умови для організації дидактичної та виховної роботи; створення та розвиток дитячих садків, якими керують органи місцевого самоврядування, громадські організації, приватні особи, які можуть краще реагувати на потреби дітей та очікування батьків на більш високий рівень опіки та виховання дітей. Проте розвиток таких установ незначний [18].

На основі аналізу праць українських (М. Бабияж, А. Василюк, В. Пасічник, К. Савина, Л. Ляшенко, Л. Гриневич, К. Корсак) і польських (Е. Сьвідерський, Е. Лодзінська) дослідників, С. Деркач підкреслює, що комплексна та глибока реформа освіти в Польщі, яка розпочалася у 1990-х роках, охоплювала структуру системи освіти, іï зміст, управління та фінансування, а також систему контролю та оцінки компетенцій, навичок та знань дітей [7]. Вступ Польщі до Європейського Союзу та соціально-економічні зміни, пов'язані $з$ цим, призвели до реформування польської освіти [9]. Зміни в польській економіці, а також в політичних та соціальних структурах, на думку С. Деркач, не могли не мати впливу на систему освіти. Туг виділяються наступні тенденції змін: збільшення нерівномірного рівня освіти; демонополізація та децентралізація управління освітніми закладами; впровадження нових програм [7].

Поглиблення цілісності навчання і виховання було прийнято як основа реформування освіти, що, у свою чергу, означало привести польську освіту до рівня середнього європейського стандарту. Після впровадження реформи програми вихователь зобов'язаний розробити програму, адаптовану до освітніх потреб дитини.

Децентралізація управління освітою $є$ характерною рисою освітніх систем різних країн. У європейській рапорті про якість освіти децентралізація освіти визначається як одна 3 п’яти ключових проблем майбутнього. Зазначено, що переміщення процесу прийняття рішень на рівні освітньої установи (школи/дошкільної установи) є важливим елементом політичної стратегії, що виникає через відсутність впевненості у здатності держави адекватно реагувати на потреби населення. Право на прийняття рішення повинні мати ті, яких торкаються результати їх реалізація $[6,151]$. 


\section{РЕФОРМУВАННЯ ДОШКІЛЬНОЇ ОСВІТИ ПОЛЬЩІ У ДОСЛІДЖЕННЯХ УКРАЇНСЬКИХ НАУКОВЦІВ}

С. Сисоєва і Т. Кристопчук у монографії "Освітні системи країн європейського союзу: загальна характеристика" один розділ присвячено системі освіти в Польщі, Аналізуючи польську систему освіти, автори підкреслюють, що існують державні та приватні школи, створені після 1990 року. Система освіти фінансується державою. Право на освіту з 1991 року надається всім дітям, включаючи тих, хто має спеціальні освітні потреби, на всіх рівнях освіти. Серед освітніх завдань XXI ст. стосовно європейських систем освіти, автори вказують на створення відкритого освітнього простору, надання привабливості освіті, підтримка активного громадянина, надання рівних можливостей та соціальної згоди [12]. На їхню думку, одним із основних елементів освіти $\epsilon$ інтенсивне навчання іноземної мови. Розвиток системи освіти на основі рідної мови плюс дві іноземні мови здійснюється шляхом запровадження реформ у дошкільній та початковій Естонії, Франції, Німеччини, Литви, Словенії та Іспанії. Пріоритетним напрямом в освітніх системах європейських країн було досягнення рівних можливостей у сфері освіти, надання всім громадянам базових знань, умінь та навичок, необхідних для соціальної та професійної інтеграції в суспільстві, в якому вони живуть. В останні роки, на їх думку, зростаюча міграція громадян стала головною проблемою для всіх європейських країн. Саме тому багатокультурність освіти є пріоритетом у системах освіти країн Європейського Союзу. Це вимагає вдосконалення системи освіти, по-перше, залишаючи $\dddot{1}$ ідентичність, по-друге, враховуючи ситуацію, шукати нові перспективи у розвитку багатокультурності навчання та виховання шляхом формування поваги до інших культур.

В. Рагозіна, досліджуючи систему дошкільної освіти Польщі, підкреслює необов'язкове відвідування дошкільної установи дітьми трьохп'яти років [11]. Дошкільна освіта намагається вирішити багато проблем, насамперед, пов'язаних з низьким відсотком охоплення дітей дошкільною освітою, короткотривалим перебуванням у закладах дошкільної освіти (особливо в сільській місцевості), недостатньою кількістю альтернативних інституцій тощо [5].

А. Василюк вважає, що для поліпшення окресленої ситуації сприяла розробка “Основ навчальної програми для дошкільної освіти” (1999 р.), на основі якої освітяни створюють власні, авторські програми. Як характерну особливість польської дошкільної освіти є проведення занять тривалістю 60 хвилин у різновікових групах. Додаткові заняття, наприклад, музика, іноземна мова тривають 15 хвилин для дітей $3-4$ років $і$ півгодини для дітей $5-6$ років. У приміщеннях, обладнаних мультимедійними та аудіовізуальними засобами, проводяться заняття 3 музики, театру та живопису. Ранній розвиток дітей дошкільного віку належить до пріоритетних завдань системи освіти Польщі.

Аналізуючи системи дошкільної освіти за кордоном в аспекті раннього естетичного розвитку дітей, зокрема в галузі художньої та естетичної діяльності, В. Рагозіна робить наступні висновки:

1. Кожна країна має свої особливості та специфіку у змісті та організації дошкільної освіти. Це стосується виховання дітей, яке для більшості країн на початку XXI століття є одним 3 найактуальніших завдань у розвитку дошкільної освіти. У той же час Польща тільки розпочинає ранній розвиток дітей у системі дошкілля i перебуває в стадії теоретичного та практичного досвіду.

2. У різних країнах світу початок ранньої освіти в системі дошкілля коливається від народження (Великобританія, Японія), від щорічних (Швеція), дворічних (Франція, США) та в деяких країнах, таких як Австралія - від трьох років. Дошкільна освіта та розвиток відбувається у різних типах закладів дошкільної освіти. Більшість - це державні дитячі садки, інші приватні, сімейні тощо, засновані благодійними фондами, релігійними організаціями, підприємствами, фондами, фізичними особами.

3. Вихованням дітей у деяких країнах займаються тільки педагоги 3 вищою освітою (Японія), адаптовані до розвитку дитини дошкільного віку, зокрема, до музики тощо. Значна роль у цьому відіграє художня та естетична діяльність дітей, їх спрямованість на різні види зацікавлень - малювання, спів, гра на простих музичних інструментах, заняття у театральних гуртках тощо.

4. Зміст освіти та виховання в країнах у всьому світі визначається нормативними положеннями.

5. Естетична (художня) освіта відіграє важливу роль у дошкільній освіті всіх країн.

6. В освітньому процесі закладів дошкільної освіти різних країн в останні десятиліття активно використовуються теоретичні та практичні досягнення видатних вихователів кінця XIX - XX ст. - С. Френета, М. Монтессори та інші.

Заслуговують на увагу визначення та аналіз основних напрямів реформування системи освіти в Польщі, зроблені С. Бочаровим [4, 24]. Він звертає увагу на найбільш проблемні питання модернізації освіти, зокрема на динаміку та 


\section{РЕФОРМУВАННЯ ДОШКІЛЬНОЇ ОСВІТИ ПОЛЬЩІ}

\section{У ДОСЛІДЖЕННЯХ УКРАЇНСЬКИХ НАУКОВЦІВ}

результати реформи освіти Республіки Польща в контексті іiі відповідності стандартам Європейського Союзу. Автор стверджує, що Україна може використовувати досвід Польщі у процесі вдосконалення власної системи освіти. До 1989 р. система освіти ПНР відповідає ідейним (комуністичним) потребам, спрямованих на виховання людини. Починаючи з 1989 р. освіта в Польщі відійшла від цих стандартів та зосередила увагу на інших цінностях, заснованих на демократії, гуманізмі та взаємній повазі. Це було наслідком значних змін у політичній системі держави, а також новим потребам польського суспільства у $1980-x$ роках $[15,8]$. А саме: виклики цивілізації, криза польської системи освіти, європейська інтеграція [14, 3]. Кожна 3 цих потреб вимагала значних змін у тодішній системі освіти. I ці зміни були зроблені у формі реформ.

С. Бочаров викоремлює умовно два етапи. Перший етап (1989 - 1999) - розробка нової освітньої програми, децентралізація системи освіти (передача навчальних закладів до провідних муніципалітетів), розвиток нових типів шкіл, а також зміни в системі екзаменів. Другий етап (3 1999 р. - до сьогоднішнього дня) - переважно пов'язаний зі змінами у змісті освіти. На його думку, хронічна економія коштів, яка була викликана економічною кризою початку 90-х років, що, у свою чергу, вплинуло на стагнацію системи освіти та спричинило значні соціальні проблеми у цій сфері. Перехід освіти під керівництво муніципалітетів не призвело одразу до позитивних змін. Ефект цього було, по-перше, ліквідація деяких шкіл та дитячих садків, оскільки муніципальні бюджети були занадто малими. Особливо постраждали дитячі садки та маленькі школи. У 1990/1991 н.р. у Польщі було 1,231,869 дитячих садків, у 1996/97 рр. їх залишилося 983,489 [15, 30].

Адміністративна реформа 90-х років ХХ ст. значно вплинула на систему освіти в Польща. У сфері освіти відбулася децентралізація. Перехід від центральної до децентралізованої системи освіти означав, що школи та інші навчальні заклади стали власністю органів місцевого самоврядування, а органи центральної влади втратили прямий адміністративний контроль над школами. Рішення польського уряду про децентралізацію системи освіти пояснюється тим, що органи місцевого самоврядування краще знають ситуацію у своїх школах та можугь ефективніше управляти ними. Представники органів місцевого самоврядування знайомі зпотребами місцевоїосвіти, томувони можугь адаптувати свою освітню політику до них [8].
Що стосується змін у структурі освіти, то реформа загальної школи призвела до стандартів, необхідних для інтеграції польського суспільства 3 європейською спільнотою. Це не означає безглуздого копіювання освіти країн $Є С$, однак наближає якість освіти до європейських стандартів [13].

Цінним $є$ порівняльне дослідження системи управління закладами дошкільної освіти в Польщі і Україні, проведені Ю. Антонюк [1]. Протягом 90-х років відбувся активний огляд загального підходу до виховання дітей дошкільного віку, визначення нової концептуальної основи функціонування дошкільних установ. Це знайшло відображення в нормативно-правовій базі, концепціях реформування системи дошкільної освіти. Серед актуальних проблем дошкільних установ Польщі та України виокремлено: криза країн, недостатнє фінансування, розмір плати за утримання дітей у дошкільній установі по відношенню до середньої заробітної плати, необхідність оптимізації безпеки та науковометодичної підтримки у процесі навчання, перевантаження дошкільних установ. Дослідниця підкреслює, що існування та розвиток дошкільних установ в Україні почалося набагато раніше, ніж у Польщі. Але головною проблемою обох країн $є$ фінансування дошкільної освіти. У Польщі одним 3 шляхів подолання цієї проблеми була децентралізація освіти, у тому числі дошкільної. На іii думку, слід звернути увагу на цей досвід і взяти його на покращення управління закладами дошкільної освіти в Україні. Однак важко передбачити графік та наслідки реформи, яка ще не була повністю розпочата. Варто зосередити увагу на необхідності реалізації державногромадського управлінського партнерства, заснованого на маркетинговій політиці, відкритих відносинах держави та державному управлінні дитячих садків, визначенні перспективи подальших наукових досліджень у цьому напрямку.

I. Бондаренко підкреслює, що освіта в Польщі на початку третього тисячоліття наближається до загальноєвропейських стандартів освіти і виховання. Освітні реформи, розпочаті з 1990-х років, зосереджені на цьому. Особливо серйозні реформи в системі освіти в Польщі відбулися в 90-х роках минулого століття. У процесі модернізації дошкільної освіти потрібно не лише визнати право дитини на щасливе дитинство, але, насамперед, створити для нього реальні умови. Перебування дитини у державному закладі дошкільної освіти протягом п'яти годин $є$ безкоштовним. За кожну додаткову годину батьки 


\section{РЕФОРМУВАННЯ ДОШКІЛЬНОЇ ОСВІТИ ПОЛЬЩІ}

У ДОСЛДЖЕННЯХ УКРАЇНСЬКИХ НАУКОВЦІВ

повинні платити. Автор наводить приклад Варшави, де додаткова година коштує три злотих, а для цього потрібно додати плату за їжу- близько восьми злотих на день [3].

Реформа дошкільної освіти спрямована на виховання людини XXI століття - гармонійно розвиненої особистості, впевненої у собі, професійно підготовленої, здатної самостійної мислити. Досвід Польщі показує, що незважаючи на фінансові труднощі, 3 якими стикалася польська освіта в першій половині 1990-х років, перехід навчальних закладів під управління муніципалітетів продовжує приносити позитивні зміни у вихованні активних, самодостатніх, незалежних та творчих громадян.

Висновки. Аналіз педагогічної літератури засвідчив, що українські дослідники вбачають ключовими для змін дошкільної освіти децентралізацію влади та передачу дошкільних установ у керівництво місцевої влади. На початковому етапі це мало як позитивні, так і негативні наслідки. До позитивних належать краще знання потреб і очікувань навколишнього середовища стосовно закладів дошкільної освіти. До негативних - фінансові проблеми органів місцевої влади та, як наслідок, ліквідація багатьох дошкільних установ.

Українські дослідники підкреслюють значення вступу Польщі до Європейського Союзу та пов'язані з цим зміни у дошкільній освіті. Вони вказують, серед іншого: можливість створення і функціонування дошкільних установ юридичними та фізичними особами, розробка єдиної програмної бази, можливість вибору та розробка вихователями програм, впровадження ранньої підтримки розвитку дитини, впровадження вивчення іноземної мови в дошкільних установах та використання інноваційних методів. Як характерний елемент польської дошкільної освіти українські науковці вказують на проведення занять у різновікових групах. Вони також звертають увагу на правила набору до дошкільних установ, зокрема, що саме батьки вирішують, в якому віці вони віддають дитину до закладу дошкільної освіти і на скільки годин. 3 появою полікультурності нового значення набирає проблема інтеграції та толерантності, 3 одного боку, i, з іншого, патріотичної та регіональної освіти. Сьогодні важливо виховувати нові покоління у власній традиції, а також бути відкритим до інших.

Подальшого висвітлення потребують проблеми організації недержавних закладів дошкільної освіти у Польщі, психолого-педагогічний супровід роботи з обдарованими дітьми.

\section{ЛІТЕРАТУРА}

1. Антонюк Ю.Р. Компаративний аналіз системи управління дошкільними навчальними закладами в Польщі та Україні / Ю.Р. Антонюк. pdf. 13 с. Дата доступу: 20.10.2017.

2. Бабияж М. Сельская школа в Польше / М. Бабияж // Педагогика. - 2006. - № 1. - С. 106-110.

3. Бондаренко І.П. Дошкільна освіта в Україні і Польщі / І.П. Бондаренко. pdf. - С. 68-75. Дата доступу: 14.09.2017.

4. Бочаров С.В. Модернізація польської системи освіти на рубежі XX - XXI століть / С.В. Бочаров // Наука. Релігія. Суспільство. - 2009. - №3. C. 23-27.

5. Василюк А.В. Стан і тенденції дошкільної освіти в Польщі / А.В. Василюк // Наукові записки НДУ ім. М. Гоголя. Психолого-педагогічні науки. - 2006. - №5. - С. 171.

6. Гриневич Л. Децентралізація управління освітньою системою (на прикладі Польщі) / Л. Гриневич // Освіта і управління. - 2004. - Т. 7. - №3-4. - С. 153-160.

7. Деркач С. Освітні реформи в Польщі/ С. Деркач // Психолого-педагогічні проблеми сільської школи. - 2007. - № 21. - С. 158-162.

8. Децентралізація освіти та реформа міжбюджетних відносин мають узгоджуватися між собою [Електронний ресурс] // Інформаційний бюлетень Міжнародного центру перспективних досліджень від 5 березня 2001 року. - №99. - http:/ /www.icps.com.ua

9. Корсак К. Про національні і світові “стандарти” середньої освіти / К. Корсак // Рідна школа. - 1999. - №4. - С. 11-14.

10. Лугіна О. Дошкільна освіта Польщі: аналіз змін / О. Лугіна // Наукові Записки. Серія: Педагогічні Науки. - Вип. 107 (2). - С. 1-7.

11. Рагозіна В. Ранній естетичний розвиток дітей у системі дошкілля зарубіжних країн [Електронний ресурс] / В. Рагозіна. - Режим доступу: http://www.ird.npu.edu.ua/files/ragozina. pdf., 14.09.2017.

12. Сисоєва С., Кристопчук Т. Освітні системи країн європейського союзу: загальна характеристика / С. Сисоєва, Т. Кристопчук. Рівне: Овід, 2012. -352 с.

13. Федорик Ю.В. Реформи польської освіти: досягнення й перспективи [Електронний ресурс] / Федорик Ю.В. // Збірник наукових праць Бердянського державного педагогічного університету (Педагогічні науки). - Бердянськ: БДПУ, 2005. - № 1. - Режим доступу: http:// www.bdpu.org/scientific_published/ pedagogics_1_2005/27.

14. Bogaj A. Realia i perspektywy reform 
oświatowych / A. Bogaj - Warszawa: Instytut Badań Edukacyjnych, 1997. - 290 s.

15. Edukacja w procesie przemian społecznych / Red. A. Bogaj, S. Kwiatkowski, M. Szymański. Warszawa: Instytut Badań Edukacyjnych. - 1998. $219 \mathrm{~s}$.

16. Grębska H., Brańska E. Wychowanie przedszkolne w nowych uwarunkowaniach społeczno-ekonomicznych / H. Grębska, E. Brańska // Wychowanie w Przedszkolu. - 1991. - № 2. - S. 815.

17. Kielar M. Potrzeby i możliwości poznawcze dziecka / M. Kielar // Wychowanie w Przedszkolu. 1992. - №1. - S. 5-11.

18. Lewowicki T. Oświata w okresie transformacji ustrojowej / T. Lewowicki // Edukacja. - 1995. - № 2. - S. 4-9.

\section{REFERENCES}

1. Antoniuk, J.R. (2017). Komparatyvnyi analiz sistemy upravlenia doshkilnymi navchalnymi zakladami v Polshi ta Ukraini [Initiative analysis of the kindergarten management system in Poland and Ukraine] pdf., 13 p. (accessed 20.10.2017). [in Ukrainian].

2. Babiarz, M. (2006). Selskaia shkola v Polshe [Rural school in Poland]. Pedagogika, no. 1, pp. 106110. [in Russian].

3. Bondarenko, I.P. (2017). Doshkilna osvita $v$ Ukraini i Polshi [Pre-school education in Ukraine and Poland]. pdf., pp. 68-75. (accessed 14.09.2017). [in Ukrainian].

4. Bocharov, S.V. (2009). Modernizacia polskoi systemy osviti na rubezhy $X X-X X I$ stolet [Modernization of the Polish education system at the turn of the XX-XXI century]. Nauka. Religia. Suspilstvo, no.3, pp. 23-27. [in Ukrainian].

5. Vasiliuk, A.V. (2006). Stan i tendencii doshkolnoj osvity $v$ Polshi [The condition and trends of pre-school education in Poland]. Naukovi zapysky NDU im. M. Gogolia. Psyhologo-pedagogichni nauki, no.5, p. 171. [in Ukrainian].

6. Grinevich, L. (2004). Decentralizacia upravlenia osvitnoiu systemoiu (na prikladi Polshi) [Decentralization of the management of the educational system (on the example of Poland)]. Osvita i upravlina, vol. 7, no, 3-4., pp. 153-160. [in Ukrainian].

7. Derkach, S. (2007). Osvitni reformy v Polshi [Educational reforms in Poland]. Psyhologopedagogichni problemy silskoj shkoly, no.21, pp. 158-162. [in Ukrainian].

8. Decentralizacia osvity ta reforma mizhbiudzhetnyh vidnosyn maiut uzgodzhuvatysa mizh soboiu [Decentralization of education and reform of budget relations should be agreed among themselves]. Informaciinyi biuleten Mizhnarodnogo centru perspektivnyh doslidzhen vid 5 bereznia 2001 roku. No. 99. Available at: http://www.icps.com.ua. [in Ukrainian].

9. Korsak, K. (1999). Pro nacionalni i svitovi "standarty" serednoj osvity [National and world "standards" of secondary education]. Ridna skola, no. 4, pp.11-14. [in Ukrainian].

10. Lugina, O. Doshkilna osvita Polshi: analiz zmin [Pre-school education in Poland: analysis of changes]. Naukovi Zapisky. Seria: Pedagogichni Nauki, vol. 107(2), pp. 1-7. [in Ukrainian].

11. Ragozina, V. (2017). Rannij estetichenyi rozvitok ditej u systemi doshkilia zarubizhnykh krain [Early aesthetic development of children in the preschool system of foreign countries]. Available at: http:/ /www.ird.npu.edu.ua/files/ragozina.pdf., (accessed 14.09.2017). [in Ukrainian].

12. Sisoeva, S. \& Kristopchuk, T. (2012). Osvitni systemy krain evropejskogo soiuzu: zagalna kharakteristika [Educational systems in the countries of the European Union: general characteristics]. Rivne: Ovid, p. 352. [in Ukrainian].

13. Fedorik, J. V. (2005). Reformy polskoi osvity: dosiagnenia $i$ perspektivy [Reforms of Polish education: achievements and perspectives]. Zbirnik naukovyh prac Berdianskogo derzhavnogo pedagogichnogo universytetu (Pedagogichni nauki). No. 1, Berdiansk: BDPU, Available at: http:// www.bdpu.org/scientific_published/ pedagogics_1_2005/27. [in Ukrainian].

14. Bogai, A. (1997). Realia i perspektyvy reform osviatovykh [Realities and prospects of educational reforms]. Varshava: Instytut Badan Edukacyinyh, p. 290. [in Polish].

15. Bogai, A., Kviatkovski, S. \& Shymanski, M. (Eds.). (1998). Edukacia $w$ procesie pzhemian spolechnykh [Education in the process of social change]. Varshava: Instytut Badan Edukacyinykh, p. 219. [in Polish].

16. Grebska, H. \& Branska, E. (1991). Wykhowanie pzhedshkolne wnovych uvarunkovaniakh spolechno-ekonomichnykh [Pre-school education in new socio-economic conditions]. Vykhovanie $w$ Pzhedshkolu, no. 2, pp. 8-15. [in Polish].

17. Kielar, M. (1992). Potzheby i mozliwosci poznavche dziecka [The child's needs and cognitive abilities]. Vykhovanie w Pzhedshkolu, no. 1. pp. 511. [in Polish].

18. Levovicki, T. (1995). Osviata $w$ okresie transformacii ustroiovei [Education in the period of political transformation]. Edukacia, no.2, pp. 4-9. [in Polish].

Стаття надійшла до редакції 26.02.2018 